\title{
MAKNA MANUHIR DALAM KEHIDUPAN MASYARAKAT DAYAK NGAJU DI KOTA PALANGKA RAYA
}

\author{
Desi Natalia ${ }^{\mathrm{a}, 1, *}$, Jefry Tarantang ${ }^{\mathrm{b}, 2}$, Ni Nyoman Adi Astiti ${ }^{\mathrm{c}, 3}$ \\ ${ }^{a}$ Institut Agama Kristen Negeri Palangka Raya, Jl. Tampung Penyang, Palangka Raya 73112, Indonesia \\ ${ }^{b}$ Institut Agama Islam Negeri Palangka Raya, Jl. G.Obos Islamic Center, Palangka Raya 73112, Indonesia \\ c Sekolah Tinggi Ilmu Hukum Tambun Bungai, Jl. Sisingamangaraja No.35, Palangka Raya 74874, Indonesia \\ ${ }^{1}$ desi.nataliaahad@gmail.com*; ${ }^{2}$ jefry.tarantang@iain-palangkaraya.ac.id; ${ }^{3}$ nyoman.adiastiti@yahoo.com
}

Article history:

Received : 2020-06-16

Revised : 2020-06-20

Accepted : 2020-06-24

Keywords:

Manuhir

People

Dayak Ngaju

Kata kunci:

Manuhir

Masyarakat

Dayak Ngaju
It was known that Dayak people as well as other tribes had its own norms and laws, known as Hadat in every activity and situation. This was also performed by Ngaju Dayak society in discarding a hunch, namely manuhir. Manuhir is an alternative healing carried out by Ngaju Dayak people in ancient times to get rid of the hunches within. This paper attempted to describe Manuhir custom in the view of Ngaju Dayak people at Palangka Raya, Central Kalimantan. In addition, it was also to maintain manuhir as an alternative healing carried out by Ngaju Dayak people as an identity of Dayak Ngaju people, so that the meaning of this ritual did not face obscurity in the future. The implementation of muhuhir action indicated the obidience of Dayak Ngaju people in their customs and traditions, since this activity was a mandatory for those who have such hunches.

\section{ABSTRAK}

Diketahui bahwa suku Dayak sama halnya dengan suku-suku yang lainnya memiliki norma dan hukum mereka sendiri, yang dikenal dengan hadat dalam setiap aktivitas dan kegiatan, dan dalam setiap situasi. Hal ini juga yang dilakukan oleh masyarakat Dayak Ngaju dalam membuang firasat, yaitu manuhir. Manuhir adalah sebuah pengobatan alternatif yang dilakukan oleh masyarakat suku Dayak Ngaju pada zaman dulu untuk membuang firasat yang ada di dalam diri. Tulisan ini bertujuan untuk mendeskripsikan manuhir dalam pemahaman masyarakat suku Dayak Ngaju di Palangka Raya, Kalimantan Tengah. Selain itu, untuk mempertahankan manuhir sebagai pengobatan alternatif yang dilakukan oleh masyarakat suku Dayak Ngaju yang merupakan suatu identitas orang Dayak Ngaju, sehingga makna ritual ini tidak mengalami kekaburan untuk kemudian harinya. Pelaksanaan tindakan manuhir ini menunjukkan tentang ketaatan orang suku Dayak Ngaju dalam adat dan tradisi, karena tindakan ini wajib dilakukan bagi orang yang memiliki firasat ini.

\section{Pendahuluan}

Pemahaman tentang agama-agama penduduk yang ada di Indonesia memampukan manusia untuk melihat proyeksinya dalam keseharian kehidupannya yang akan mengakui kebenaran pendapat umum yang menyatakan masyarakat Indonesia itu adalah masyarakat yang religius. Dasar religius ini nampak dalam hal adat dan tradisi, hukum dan moral, kehidupan sosial, dan kekeluargaan ikatan kerabat. Dalam hubungan ini, para peneliti agama suku di Indonesia, para ethnolog, anthropologi, dan 
juga para theolog di masa silam sering berkesimpulan bahwa agama suku di Indonesia itu pada dasarnya sangat ditentukan oleh rasa ketakutan terhadap kuasa para roh dan ilah, khususnya menanggapi agama suku Dayak, Philip Zimmermann yang merupakan salah seorang yang mencoba meneliti agama suku Dayak mengutarakan kesimpulan yang sama (Fridolin Ukur, 1971). Setelah Mahatara (Ilah tertinggi) menciptakan alamsemesta, maka dia mengundurkan dirinya dikemahatinggian dan menyerahkan pengurusan dunia ini kepada ilah bawahannya. Agama ini pula merupakan kekuatan yang menentukan di dalam seluruh tindak kehidupan bangsa dan perorangan yang didalamnya dijumpai akar dari perasaan dan motif tindakan-tindakan mereka.

Taylor dan Spencer menganggap bahwa agama sebagai suatu hasil pemikiran manusia dan hasratnya untuk mengetahui (Eizabeth Nottingham, 1985). Ini adalah bagian dan bukan hakikat dari kebenaran itu. Durkheim dan Freud juga mengemukakan landasanlandasan agama yang bersifat naluriah dan emosional.

Clifford Geetz menulis agama adalah sebuah sistem symbol yang berperan membangun perasaan dan motivasi yang berpengaruh yang meliputi dan abdi dalam diri manusia dengan jalan merumuskan konsepsi-konsepsi itu dengan suatu pancaran faktualitas, sehingga perasaan dan motivasi itu terlihat secara unik realitas (Bellah, 1991). Dari semua yang telah diuraikan di atas menunjukkan bahwa agama itu merupakan produk kebudayaan atau pengembangan dari aktivitas manusia sebagai makhluk pencipta kebudayaan (Eizabeth Nottingham, 1985). Dengan demikian menurut pandangan sarjana Sosiologi, agama dapat dianggap sebagai sarana kebudayaan bagi manusia dan dengan sarana itu, dia mampu menyesuaikan diri dengan pengalaman-pengalamannya dalam keseluruhan lingkungan hidupnya termasuk dirinya sendiri, anggota-anggota kelompoknya, alam dan lingkungan lain yang dia rasakan sebagai sesuatu yang transcendental (tidak terjangkau penalaran manusia). Dalam lingkungan tersebut terakhir inilah, pikiran, perasaan dan perbuatan manusia terhadap hal-hal yang menurut perasaannya berada di luar jangkauan pengalaman-pengalamannya sehari-hari dengan dirinya sendiri, teman-temannya dan dengan dunia nyata, katakanlah yang sacral yang menyebabkan kita percaya dan inilah inti agama tersebut. Dengan kata lain, konsepsi agama yang diuraikan secara singkat ini bahwa agama sebagai mekanisme paling umum untuk mengintegrasikan makna dan motivasi dalam sistem-sistem tindakan, tidak hanya pada keseluruhan masyarakat maupun kelompok-kelompok masyarakat, tetapi juga banyak unit yang lebih kecil (kepribadian individu atau kelompok-kelompok) mengambil simbol-simbol keagamaan lingkungan sosial dan budaya mereka dalam rangka menghadapi berbagai masalah keagamaan mereka sendiri.

Menurut perspektif Durkheim, individu tergantung pada masyarakat (atau sekurangkurangnya pada satu kelompok tertentu dalam masyarakat itu), karena kepercayaan dan nilai yang memberi arti dan tujuan hidup dan karena norma yang membimbing dan mengatur perilaku (Doyle Paul Johnson, 1986). Sebagaimana yang disampaikan oleh Sapulette bahwa wujud nyata dari hubungan bersama akan melahirkan pengalaman emosional, sehingga memperkuat hubungan antar mereka (Sapulette, 2019).

Orang Dayak memiliki norma-norma dan hukum-hukum mereka sendiri, yang dikenal dengan hadat dalam setiap aktivitas dan kegiatan, dan dalam setiap situasi (Hans Scharer, 1963). Bagi umat manusia tidak ada tempat yang bebas dari hadat dan tidak ada waktu tanpa hadat. Hadat memerintah seluruh kehidupan, dan seseorang tidak dapat mengambil langkah, dapat memulai tetapi tidak dapat melanjutkan, tanpa bentuk, dan rangkaian keseluruhan yang ditentukan oleh hadat. Hadat adalah penuntun untuk menjalani hidup, dan seseorang harus diarahkan olehnya (dan dapat mengarahkan dirinya sendiri, jika tidak maka dia tersesat dari jalan yang benar. Senyatanya, banyak tindakan yang keluar dari kebiasaan, dan seseorang tidak selalu bertanya kepada dirinya sendiri apa yang mungkin menjadi alasan mendasar untuk bertingkah-laku dan bertindak demikian.

Seseorang akan berpikir untuk bertingkah laku dalam satu cara yang khusus dan seseorang tahu bahwa sesuatu yang khusus harus dilakukan dalam cara ini yaitu bila 
mereka benar dan tidak lepas dari adat. Berdasarkan Peraturan Daerah Provinsi Kalimantan Tengah Nomor 10 tahun 2010 Tentang Perubahan Atas Peraturan Daerah Provinsi Kalimantan Tengah Nomor 16 Tahun 2008 Tentang Kelembagaan Adat Dayak di Kalimantan Tengah. Adat atau kebiasaan yang terjadi dalam masyarakat Dayak dan berlaku berdasarkan pengalaman hidup masyarakat Dayak membentuk norma atau aturan perilaku (Pelu \& Tarantang, 2018).

Hal ini mengingatkan tentang kebudayaan memiliki peran sebagai berikut. (Setiadi, 2017)

1. Suatu hubungan pedoman antar manusia atau kelompoknya.

2. Wadah untuk menyalurkan perasaanperasaan dan kemampuan-kemampuan lain.

3. Sebagai pembimbing kehidupan dan penghidupan manusia. Pembeda manusia dan binatang.

4. Petunjuk-petunjuk tentang bagaimana manusia harus bertindak dan berperilaku dalam pergaulan.

5. Pengaturan agar manusia dapat mengerti bagaimana seharusnya bertindak, berbuat, menentukan sikapnya jika berhubungan dengan orang lain.

6. Sebagai modal dasar pembangunan.

Berkaitan dengan kebudayaan yang memiliki peran dalam suku Dayak Ngaju, khususnya dalam membuang firasat. yaitu manuhir. Manuhir adalah sebuah pengobatan tradisional yang dilakukan oleh masyarakat suku Dayak Ngaju pada zaman dulu untuk membuang firasat yang ada di dalam diri kita, yang tidak baik dalam diri kita (Alyana, 2019). Firasat ini ada dalam diri manusia yang hadir begitu saja, tanpa diketahui dari manamana asalnya. Adapun syarat-syarat yang harus dilakukan dan dilengkapi untuk mengeluarkan darah kotor ini yaitu tergantung letak dari firasat yang ada dalam diri orang tersebut.

Bilamana darah kotor ini tidak dikeluarkan menurut kepercayaan asli masyarakat Dayak Ngaju, maka orang tersebut akan mengalami mati berdarah seperti kecelakaan, disambar buaya atau tenggelam. Akan tetapi, pada zaman sekarang karena jauh dari sungai, sehingga wujud buaya berganti pada motor pada motor dan mobil, kebanyakan firasat yang yang ada sekarang adalah mati berdarah (Dajak Booven, 2010).

Berdasarkan uraian di atas, dapat dilihat bahwa manuhir memiliki peran penting dalam kehidupan masyarakat suku Dayak Ngaju untuk bertingkah laku dalam satu cara yang khusus dan seseorang mengetahui bahwa sesuatu yang khusus harus dilakukan dalam cara ini untuk mencapai suatu misi yaitu untuk memperoleh kebaikan dan keselamatan. Oleh karena itu, sangat diperlukan kajian yang mendalam tentang makna manuhir dalam kehidupan masyarakat suku Dayak Ngaju di Palangka Raya.

\section{Tinjauan Pustaka}

Sejauh pembacaan penulis terhadap karyakarya yang berkaitan dengan manuhir, studi tentang manuhir masih merupakan kajian yang langka. Studi-studi yang dilakukan masih fokus pada soal hadat dan pali. Hal ini misalnya bisa dilihat dalam karya yang ditulis oleh Hans Scharer, dengan judul "Ngaju Religion The Conception of God Among A South Borneo People" (1963). Karya tersebut memandang hadat adalah perintah, sedangkan kata pali adalah larangan (Hans Scharer, 1963). Pali atau larangan jumlahnya sangat banyak, dan ada sejumlah kategori yang berbeda, yang masing-masing dengan tujuannya sendiri-sendiri. Tidak ada kepentingan kita untuk masuk ke dalam halhal ini. Pali mengelilingi manusia seperti manusia pagar, menjaga dia agar di dalam batasan hadat, dan menuntun dia pada jalan yang benar. Pali atau larangan sama seperti rambu-rambu yang diletakkan di tempattempat berbahaya pada jalur perjalanan manusia, untuk memanggil dia kembali dari jalan lain yang tidak aman dan untuk mencegah dia tersesat dan menuju bahaya. Hans Scharer mengatakan bahwa hadat dan pali adalah satu kesatuan. Pelanggaran atas hadat dan pelanggaran atas pali adalah identik, karena itu adalah pali untuk melanggar hadat, dan memperdulikan pali adalah hidup di dalam dan oleh hadat. Tulisan Hans Scharer ini memang menarik, tetapi belum ada memaparkan tentang hadat dalam tindakan manuhir pada suku Dayak Ngaju yang di dalamnya terdapat muatan tentang alasan tersendiri mengapa orang Dayak Ngaju melakukan ritual ini. 
Tulisan lain yang memaparkan hadat dan pali ditulis oleh Nila Riwut dengan judul Maneser Panatau Tatu Hiang atau Menyelami Kekayaan Leluhur (Nila Riwut, 2003). Karyanya ini menggambarkan bahwa konsep kepercayaan suku Dayak, manusia juga makhluk lainnya telah ditentukan dan ditugaskan dalam kedudukan masing-masing untuk memenuhi fungsinya guna memelihara tata ketertiban alam. Tata keserasian dan tata keseimbangan kosmos inilah yang dikalangan suku Dayak dinamakan hadat. Tulisan Nila Riwut ini mengatakan bahwa manusia dikatakan baik atau sempurna, apabila ia mampu menjalankan seluruh hukum adat dan mentaati hukum pali. Tulisan Nila Riwut ini tidak menguraikan lebih mendalam tentang hadat orang Dayak untuk mencapai keselamatan dan ketenangan yang diperoleh dengan melakukan manuhir dalam suku Dayak Ngaju.

Karya lainnya yang memaparkan tentang pali adalah Kajian Sosio-Teologis terhadap Pali Hari Selasa dalam Tradisi Masyarakat Suku Dayak Ngaju di Desa Batu Nyiwuh Kecamatan Tewah Kabupaten Gunung Mas yang ditulis oleh Dewi Sinta . Tulisannya ini adalah skripsi yang ada di STAKN Palangka Raya. Dalam tulisannya ini, Dewi Sinta menuliskan bahwa tradisi diartikan di sini sebagai serangkaian pola perilaku yang dinilai tinggi, yang telah diwariskan secara turun temurun dari satu generasi ke generasi berikutnya (Dewi Sinta, 2018). Salah satu tradisi masalah pali hari Selasa, dapat diartikan sebagai serangkaian aturan yang melarang sekelompok masyarakat melakukan suatu tindakan tertentu.

Dewi mengatakan bahwa masyarakat Kalimantan Tengah, khususnya di Batu Nyiwuh masih berkeyakinan pali juga berkaitan erat hubungannya dengan hari baik atau hari kurang baik, sehingga sebagian masyarakat suku Dayak Ngaju di Batu Nyiwuh tidak melakukan sesuatu tertentu di hari Selasa yang diyakini sebagai hari kurang baik, karena akan berdampak bagi yang melanggarnya (Dewi Sinta, 2018). Sebab pali yang benar-benar tabu terkait dengan sesuatu yang bersifat sakral atau berdampak buruk bagi orang yang melanggarnya. Dewi menggunakan salah satu acuan tulisannya karangan Nila Riwut (Maneser Panatau Tatu Hiang atau Menyelami Kekayaan Leluhur), bila terjadi pelanggaran akan sangat fatal akibatnya, karena hukuman akan ditanggung oleh banyak pihak, dan alam akan menghukum mereka. Dalam tulisan Dewi ini, dia mengaitkan bahwa dalam Perjanjian Lama menurut kitab Kejadian Pasal 1 yang pertamatama diciptakan ialah terang, tahapan kedua cakrawala, tahapan ketiga laut dan darat bersama tumbuh-tumbuhan, tahapan keempat matahari, bulan, dan bintang-bintang, tahapan kelima, ikan dan burung, tahapan keenam binatang, darat, dan manusia (Dewi Sinta, 2018). Menariknya dalam citra penciptaan itu bahwa setiap kali Allah mencipta, tahapan waktu atau kejadiannya selalu dinilainya dengan "baik." Pada kenyataannya di dalam masyarakat Dayak Ngaju desa Batu Nyiwuh masih meyakini bahwa ada hari yang tidak baik. Tulisan Dewi Sinta memang menarik dengan memfokuskan tentang pali Hari Selasa dalam Tradisi Masyarakat Suku Dayak Ngaju di Desa Batu Nyiwuh Kecamatan Tewah Kabupaten Gunung Mas bila terjadi pelanggaran akan sangat fatal akibatnya, karena hukuman akan ditanggung oleh banyak pihak, dan alam akan menghukum mereka. Hal ini yang membuat berbeda dari akibat yang diterima oleh orang yang memiliki firasat itu akan menanggung akibatnya sendiri.

Tulisan-tulisan yang dipaparkan ini telah membantu penulis, karena memberi informasi awal kepada penelitian yang akan penulis lakukan. Sayangnya tulisan-tulisan tersebut hanya memberi gambaran singkat dan jauh dari memadai dipandang dari perspektif akademis untuk pemahaman tentang makna manuhir.

\section{Metodologi Penelitian}

Penelitian ini adalah penelitian kualitatif. Penelitian kualitatif adalah penelitian yang digunakan untuk meneliti pada kondisi objek alamiah dimana peneliti merupakan instrumen kunci (Siti Zaenab, 2015). Peneliti berupaya untuk menggambarkan, menganalisis, serta menginterpretasikan kesatuan-kesatuan dari variabel-variabel yang diteliti, melalui pengamatan terhadap fakta-fakta yang berkaitan dengan permasalahan pokok, serta fenomena-fenomena yang terdapat dalam masyarakat, secara khusus yang berkaitan dengan pokok penelitian. Pendekatan ini akan menghasilkan data deskriptif berupa kata-kata 
lisan serta kumpulan perilaku dari masyarakat yang diteliti, secara sistematis, faktual dan akurat.

Penelitian dilaksanakan di Kalimantan Tengah, khususnya di Palangka RayaKalimantan Tengah. Penelitian ini akan berlangsung kurang lebih satu bulan.

Satuan analisis yang digunakan adalah seorang pribadi sebagai sumber partisipan yang berhubungan dengan masalah yang akan diteliti. Peneliti akan melakukan wawancara mendalam dengan satu orang sebagai informan kunci untuk mengetahui pemahamannya tentang manuhir dalam suku Dayak Ngaju di Palangka Raya.

Analisis data ini dilakukan secara induktif yaitu dengan cara menarik kesimpulan atas data yang berhasil dikumpulkan di lapangan dari yang berbentuk khusus ke bentuk umum. Hasil penelitian ini tentunya menarik kesimpulan dari beberapa hasil temuan yang diperoleh dari lapangan.

\section{Hasil dan Diskusi}

Seorang sarjana Durkheim sangat kuat komitmennya untuk mengambil sikap obyektif dalam analisanya yang secara teguh didasarkan pada fakta (Johnson, 1986: 169). Keterlibatannya yang langsung dalam pelbagai masalah sosial atau politik dan komitmen ideologisnya tidak pernah mempengaruhi penelitian yang tidak memihak atau yang obyektif tentang pengetahuan.

Pendiri ideologis Durkheim secara pribadi bersifat liberal. Walaupun mudah untuk melihat beberapa implikasi konservatif penting dalam karya teoritisnya, sebagiannya karena tekanan yang terlampau mementingkan struktur sosial serta kepatuhan individu terhadap masyarakat secara mutlak untuk perkembangannya. Misalnya, tradisi yang dilahirkan oleh manusia merupakan adat istiadat, yakni kebiasaan namun lebih ditekankan kepada kebiasaan yang bersifat suprantural yang meliputi dengan nilai-nilai budaya, norma-norma, hukum dan aturan yang berkaitan (Darwis, 2017). Hal ini nampak pada orang Dayak Ngaju yang melaksanakan tindakan manuhir. Tindakan manuhir adalah salah satu kebudayaan yang ada dalam suku Dayak Ngaju di Palangka
Raya, Kalimantan Tengah. Tindakan ini tidaklah sama dengan suku yang lainnya. Sebab di Indonesia yang terdiri dari berbagai macam suku bangsa yang berbeda, tetapi setiap kebudayaan mempunyai ciri atau sifat yang sama. Sifat tersebut bukan diartikan secara spesifik, melainkan bersifat universal. Sifat-sifat budaya itu akan memiliki ciri-ciri yang sama bagi semua kebudayaan manusia tanpa membedakan faktor ras, lingkungan alam, atau pendidikan.

Manuhir adalah pengobatan tradisional orang Dayak yang dilakukan secara turuntemurun untuk membuang firasat ataupun sesuatu yang tidak baik yang ada di dalam diri seseorang. Tindakan manuhir ini memang wajib dilakukan oleh orang yang mempunyai firasat tersebut (Alyana, 2019). Sebagaimana yang disampaikan oleh Heriansyah bahwa dalam kehidupan di masyarakat juga harus tumbuh sikap bekerja sama, saling tolong menolong, menyayangi diri dan orang lain, menerima diri dan mampu mengarahkan diri (Heriansyah, 2017).

Durkheim mengemukakan tiga gejala sosial karakterisktik individu (Doyle Paul Johnson, 1986), adalah sebagai berikut:

1. Gejala sosial bersifat terhadap individu. Durkheim menegaskan bahwa "ini lalu merupakan cara bertindak, berpikir, dan berperasaan yang memperlihatkan sifat patut dilihat sebagai sesuatu yang berada di luar kesadaran individu." Hal ini nampak ketika seseorang yang pada awalnya tidak mengetahui bahwa dalam dirinya tidak memiliki firasat menjadi tahu bahwa dalam dirinya terdapat firasat yang disampaikan melalui orang yang memiliki pengetahuan akan hal ini (Alyana, 2019). Melalui perkataan orang yang menyampaikan akan adanya firasat tersebut, maka seorang pribadi yang memiliki firasat mengetahuinya melalui suatu percakapan antara kedua belah pihak tersebut. Meskipun banyak dari fakta sosial ini akhirnya diendapkan oleh individu melalui proses sosialisasi (seperti jelas yang dilihat oleh Durkheim), individu itu sejak awalnya mengkonfontasikan fakta sosial itu sebagai suatu kenyataan eksternal. 
2. Fakta itu memaksa individu. Jelas bagi Durkheim bahwa individu dipaksa, dibimbing, diyakinkan, didorong, atau dengan cara tertentu dipengaruhi oleh pelbagai tipe fakta sosial dalam lingkungan sosialnya. Seperti Durkheim katakan: "tipe-tipe perilaku atau berpikir ini.. mempunyai kekuatan memaksa yang karenanya mereka memaksa individu terlepas dari kemauan individu itu sendiri." Setelah seorang yang sudah menerima informasi akan kenyataan atau suatu fakta adanya firasat yang ada dalam dirinya, sehingga dia juga mengetahui informasi bahwa dia harus membuangnya. Apabila firasat tersebut tidak dibuang, maka dia akan menerima konsekuensi-konsekuensi yang akan dihadapinya yang tidak sesuai dengan keinginannya. Hal ini nampak juga dalam ritual buang-buang air merupakan ritual yang dilakukan sebagian penduduk Dabong untuk mengawali suatu acara yang penting seperti khitanan, menjelang kelahiran anak dan pernikahan. Menurut Saripaini dan Yusriadi, bahwa sebagian penduduk Dabong percaya jika ritual ini tidak dilakukan maka akan terjadi sesuatu yang tidak dinginkan kepada orang yang bersangkutan (Saripaini \& Yusriadi, 2016).

Tentu saja hal ini membuat ketidaknyamanan dan kekhawatiran akan sesuatu yang tidak baik dalam diri seseorang yang disampaikan oleh orang tertentu yang mampu melihat firasat yang ada di tubuh orang tersebut terhadap apa yang akan terjadi akan diri seseorang akan nantinya. Meskipun ada penolakan dalam diri seseorang terhadap firasat tersebut, bagi orang yang mampu melihatnya tetap diketahui olehnya. Sebab dia memiliki pengetahuan akan hal ini. Dia juga harus menyampaikannya kepada orang yang memiliki firasat tersebut, supaya perasaannya senang dan tidak bersalah, kalau menyampaikannya, meskipun orang yang memiliki firasat tersebut yang mendengarnya itu, baik menerima informasi tersebut maupun tidak menghiraukannya. Hal itu menjadi persoalan lain.

Ada anggapan bagi orang yang menyampaikan kepada orang yang memiliki firasat tersebut, bahwa dia merasa berdosa atau merasa bersalah, kalau dia tidak menyampaikannya. Sebab ada berbagai pikiran yang muncul dalam diri orang ini, apakah pendapatnya diterima atau tidak, sehingga kadang kala dia juga terpaksa juga untuk harus menyampaikannya secara pelanpelan, takutnya apa yang dikatakannya tidak mau menerimanya, kadang-kadang bisa takut juga kalau tidak mengetahuinya.

Dari pelaksanaan tindakan manuhir ini menunjukkan tentang ketaatan orang suku Dayak Ngaju dalam adat dan tradisi, karena tindakan ini wajib dilakukan bagi orang yang memiliki firasat ini. Hal ini terkesan bahwa fakta tersebut begitu memaksa orang yang mempunyai firasat ini harus membuang firasat tersebut. Namun satu sisi apabila, mereka mendengarkan kata orang yang berpengetahuan juga sebagai bagian dari masyarakat kesukuan. Pengertian "masyarakat kesukuan" bagi orang Dayak tidak mungkin dilepaskan dari pengertian mereka tentang persekutuan religiusnya yang menjalani suatu kehidupan yang sesuai dengan tata-kosmos yang telah diatur dan diwariskan sejak mula pertama kejadian dunia dan manusia yang dinyatakan dalam adat dan tradisi (Fridolin Ukur, 1971). Suwarno menganggap bahwa harapan ini didukung oleh kesadaran setiap individu untuk menyelaraskan setia kepentingannya dengan kepentingan bersama. Kesadaran tersebut dilandasi oleh alam pikiran religio-magis, yang menganggap bahwa setiap warga mempunyai nilai dan kedudukan serta hak hidup yang sama dalam lingkungan masyarakatnya (Suwarno, 2017).

Jika melihat evolusi hubungan manusia dengan alam di masa lampau telah terbentuk suatu hubungan yang harmonis yang disebut pan cosmism. Manusia berusaha untuk hidup selaras dengan alam. Dalam pandangan manusia pada masa itu, alam itu besar dan sakral karena itu harus dipelihara sehingga tidak terjadi kerusakan alam dan berakibat negatif bagi manusia itu sendiri. Dalam merealisasikan gagasan itu manusia menciptakan pamali-pamali atau etika bagaimana bertindak dan bertingkah laku terhadap alam (Salim, 2016). Dari ungkapan pamali ini mengandung nilai karakter disiplin. Nilai karakter disiplin artinya tindakan yang menunjukkan perilaku tertib dan patuh pada berbagai ketentuan dan peraturan (Harpriyanti \& Komalasari, 2018) yang berhubungan 
dengan nilai-nilai norma dan etika supaya menuntun ke arah yang baik dan benar (Akhlak, Arifin, \& Rijal, 2019). Pamali ini yang menurut Nurdiansah mengandung makna kata melarang sekaligus makna sanksi yang tidak bisa diukur batasannya. Ungkapan pamali ini menjadi rambu-rambu dalam mengelola alam. (Nurdiansah, 2017) yang kadang-kadang pemali dianggap Akhlak, jauh lebih dipercayai bila dibandingkan dengan hukum atau aturan undang-undang. Jika ditelusuri alasan di balik hadirnya pemali di masyarakat, maka akan ditemukan adanya pesan-pesan moral yang terkandung di dalamnya. Oleh karena itu, pamali menurut Uniawati masih tetap diwariskan kepada generasinya dengan harapan mereka dapat mematuhinya demi keselamatan dan kesuksesan hidup yang akan dihadapinya (Uniawati, 2014).

Seseorang yang menjuruskan seluruh kehidupannya, serta tindak-langkahnya untuk mematuhi, memenuhi, dan melaksanakan tata-ilahi, serta berusaha melakukan tugas dan fungsinya didalam kosmos, dialah yang dipandang selaku "manusia sempurna." Manusia baik, manusia sempurna disebut dalam bahasa Dayaknya: Oloh Bahadat (orang beradat atau orang yang mempunyai adat). Apabila seorang melanggar adat, maka dia sendiri telah menjauhkan dirinya dari wilayah berkah keilahian. Keadaan demikian sama artinya dengan penolakan oleh orang tersebut terhadap fungsi yang diserahkan kepadanya, yang pada dasarnya adalah demi keselamatan diri sendiri. Oleh ketidaktaatannya itu, maka bukan hanya dia sendiri yang telah menjatuhkan hukuman atas dirinya, melainkan juga berarti bahwa perbuatan ketidaktaatan itu ikut menimbulkan ketergangguan dalam keseimbangan kosmos, akibatnya timbullah keonaran dan kebilauan dalam tata kosmos itu sendiri (Fridolin Ukur, 1971).

\section{Dalam bahasanya Nottingham:}

Satu penjelasan yang mudah diingat ialah kekuatan adat kebiasaan-kekuatan memaksa dari adat yang bersifat absolut dan yang didukung oleh sikap ketidakpedulian manusia. Penjelasan ini menunjukkan kepada kita sebagian peranan dari mitos tersebut walaupun banyak juga yang tidak ada penjelasannya. Hal ini mengakibatkan timbulnya pertanyaan lebih lanjut, yaitu: Apa yang menyebabkan adat tersebut mempunyai kekuatan memaksa.? Dalam satu hal itu, dengan nilai (itu) masyarakat berupaya mencapai tujuan-tujuan terpenting dari kegiatan sosial (mereka); tetapi dalam hal lain mereka berusaha agar tingkah laku sehari-hari hari dari para anggota masyarakat pada umumnya sesuai dengan nilai-nilai tersebut. Standar tingkah laku-"keharusan-keharusan" yang ideal, yang membentuk nilai-nilai sosial ini, sering disebut oleh sarjana-sarjana sosiologi sebagai norma-norma sosial (Eizabeth Nottingham, 1985). Norma-norma itu terdapat dalam kerangka acuan yang bersifat sakral, maka norma-norma tersebut dikukuhkan pula dengan sanksi-sanksi sakral tersebut mempunyai kekuatan memaksa yang istimewa. Karena, tidak hanya menyangkut ganjaran-ganjaran dan hukuman-hukuman yang bersifat duniawi dan manusiawi, tetapi juga ganjaran-ganjaran dan hukumanhukuman yang bersifat supra manusiawi dan ukrawi.

Oleh karena itu, beberapa jenis persetujuan bersama atau consensus mengenai wujud kewajiban-kewajiban yang sangat penting ini, begitu juga mengenai adanya kekuatan yang mampu memaksa orang-orang dan pihak pihak (yang bersangkutan) untuk melaksanakan kewajiban-kewajiban tersebut, minimal diperlukan untuk mempertahankan ketertiban masyarakat (Eizabeth Nottingham, 1985).

Ada dua hal yang menjadi kekuatan yang mendorong orang-orang dan pihak - pihak (yang bersangkutan) itu mengorbankan kepentingan pribadi mereka demi terpenuhinya kepentingan masyarakat secara keseluruhan yaitu: Pertama, agama telah membantu mendorong terciptanya persetujuan mengenai sifat dan isi kewajibankewajiban sosial tersebut dengan memberikan nilai-nilai yang berfungsi menyalurkan sikapsikap para anggota masyarakat dan menetapkan isi kewajiban-kewajiban sosial mereka. Dalam peranan ini, agama telah membantu menciptakan sistem-sistem nilai sosial yang terpadu dan utuh. Kedua, terdapat alasan-alasan yang kuat untuk mempercayai bahwa agama juga telah memainkan peranan vital dalam memberikan kekuatan memaksa yang mendukung dan memperkuat adat istiadat. Dalam hubungan ini, patut diketahui 
bahwa sikap mengagungkan dan rasa hormat, terutama yang berkaitan dengan adat istiadat (moral) yang berlaku, berhubungan erat dengan perasaan-perasaan kagum yang ditimbulkan oleh yang sacral itu sendiri (Eizabeth Nottingham, 1985). Menurut Muhammad, bahwa "Perasaan kagum inilah untuk menarik mereka untuk cinta dan ingin terhindar dari bahaya" (Muhammad, 2013).

3. Ini tidak berarti bahwa individu itu harus mengalami paksaan fakta sosial dengan cara yang negatif atau membatasi seperti seseorang untuk berperilaku yang bertentangan dengan kemauannya. Sesungguhnya kalau proses sosialisasi itu berhasil, individu sudah mengendapkan fakta sosial yang cocok sedemikian menyeluruhnya, sehingga perintahperintahnya akan kelihatan sebagai hal yang biasa, sama sekali tidak bertentangan dengan kemauan individu. Tentu sosialisasi jarang sebegitu sempurnanya, sehingga tidak ada ketegangan sama sekali antara fakta sosial dan kemauan individu (Doyle Paul Johnson, 1986). Fakta itu bersifat umum atau tersebar secara meluas dalam satu masyarakat. Dengan kata lain, fakta sosial itu sekedar hasil dari penjumlahan beberapa fakta individu. Fakta sosial benar-benar bersifat kolektif, dan pengaruhnya terhadap individu merupakan hasil dari sifat kolektifnya ini.

Menurut Durkheim, fakta sederhana bahwa manusia adalah makhluk bersisi ganda. Di dalam diri manusia ada dua cara mengada: cara menggada individu (individual being) yang dasar-dasarnya terletak pada tubuh dan ranah tindakannya dibatasi oleh fakta tubuh tersebut dan cara mengada sosial (social being) yang mempresentasikan di dalam diri kita realitas tertinggi dalam ranah intelektual dan moral yang hanya dapat diketahui melalui pengamatan; dan yang Durkheim maksud adalah masyarakat. Dalam ranah praksis, dampak dualitas terhadap hakikat kemanusiaan kita adalah bahwa ideal moral tidak dapat direduksi menjadi semata-mata motif-motif utilitarian; dalam ranah pemikiran, rasio tidak dapat direduksi menjadi sebatas pengalaman individual. Sebagai bagian dari masyarakat, secara alamiah individu mentransendensikan dirinya, baik ketika dia berpikir maupun bertindak (Emile Durkheim, 2006).

Menurut orang suku Dayak Ngaju bahwa firasat itu kadang bisa kelihatan juga ada, dan bisa juga tidak kelihatan, yang memang tidak dapat diketahui asal-muasalnya (Alyana, 2019). Firasat ini biasanya ada tempat firasatnya, yaitu terletak di hidung, dan sekitar wajah yang ada di sana sini. Menurut Ahmad, bahwa wajah dipilih sebab menjadi ekspresi jiwa dan keadaan kesehatan seseorang untuk pertama kali untuk dibaca (Ahmad, 2018).

Berdasarkan letak firasat dan cara manuhirnya, dia sendiri yang menerima akibatnya, karena tidak mengerjakannya. Misalnya, firasatnya terletak di hidung, maka cara manuhirnya dengan mengeluarkan darah yang ada firasatnya, supaya tidak disambar buaya, tenggelam, karena yang dikatakan orang tersebut telah dilaksanakan. Walaupun seseorang yang mempunyai firasat ini tidak di air, hal yang bisa terjadi ketika berada di selokan, ataupun di drainase kalau sudah sampai waktunya, firasat kecelakaan ada. Dengan demikian, tindakan manuhir ini wajib dilakukan bagi orang yang sudah menerima peringatan dari orang yang mampu melihat firasat tersebut demi keselamatan dan ketenangan hidupnya. Dalam bahasanya Yulianti, dkk, bahwa setiap manusia pada hakikatnya ingin terhindar dari gangguan apapun, salah satunya adalah kondisi abnormalitas atau keadaan yang menyebabkan seseorang sakit (Yulianti, 2018).

Tindakan manuhir ini bermacam-macam caranya dan tidak merata. Tindakan ini tergantung firasat dan caranya juga. Kalau firasatnya berada di darat dilakukannya di darat, kalau firasatnya di air dilakukan di air orang mengerjakannya, walaupun di drainase. Tindakan manuhir dapat dilakukan di hidung, kalau firasatnya ada di hidung. Kalau firasatnya ada di pipi atau di dekat mata satu dengan mata yang lain, maka tindakannya di pipi atau dia antara mata satu dengan mata yang lainnya.

Adapun syarat-syarat yang dilakukan untuk melakukan tindakan manuhir ini juga tergantung firasatnya dan orang yang mampu membuang "sial" tersebut, yaitu dengan menggunakan beling (pecahan kaca) dan butiran emas. Beling ini digunakan untuk 
membuang firasat tersebut dengan cara menggores ke bagian kulit yang diketahui ada firasatnya. Setelah firasat tersebut sudah dibuang, maka bekas luka tersebut diberikan butiran emasnya. Hal inipun tergantung dari orang yang melakukan tindakan manuhirnya dan syarat-syaratnya pun tergantung dari kesepakatan kedua belah pihak, baik dari orang yang memiliki firasat maupun orang yang mampu mengeluarkan firasat tersebut untuk menyediakan dan menyiapkannya, supaya memperoleh keselamatan dan ketenangan dalam hidupnya sebagai bentuk ketaatan dalam adat dan tradisi. Apabila tindakan manuhir itu sudah dilaksanakan, maka firasat itu juga telah hilang menurut keyakinan orang tersebut dan orang yang telah melaksanakan tindakan tersebut. Dengan demikian, seorang individu yang telah melakukan tindakan manuhir ini menjadi tenang, tidak kepikiran, dan selamat dari yang telah disampaikan oleh orang yang mampu melihat firasat tersebut (Alyana, 2019).

Apabila firasat tersebut sudah dibuang, maka bekas firasat tersebut itu memang tidak boleh ditunjukkan kembali atau orang lain menunjukkan kembali, karena sudah lepas, hilang. Akan tetapi ini tergantung diri seseorang saja.

Ketiga karakteristik ini merupakan eksternalitas, paksaan, dan sifat umum menggambarkan tipe gejala yang dilihat oleh Durkheim sebagai pokok permasalahan dalam sosiologi. Durkheim menegaskan bahwa kemungkinan untuk merembukkan persetujuan-persetujuan kontraktual itu dengan mereka yang belum memiliki ikatan sosial yang sama. Sekurang-kurangnya sudah ada konsensus moral yang berhubungan dengan sifat kontrak yang mengikat itu (Doyle Paul Johnson, 1986).

Sebagaimana Durkheim mengatakan, bahwa persepsi individu tentang kepentingan pribadinya tidak dibentuk dalam isolasi dari sesamanya, melainkan dibentuk oleh kepercayaan bersama serta nilai-nilai yang dianut bersama orang-orang lainnya dalam masyarakat. Masyarakat adalah manusia yang merupakan makhluk yang berbudaya, melalui akalnya manusia dapat mengembangkan kebudayaan. Begitu pula manusia hidup dan tergantung pada kebudayaan sebagai hasil ciptaannya.
Kebudayaan mempunyai fungsi yang besar bagi manusia dan masyarakat, berbagai macam kekuatan harus dihadapi manusia dan masyarakat (seperti kekuatan alam dan kekuatan lain) dan memerlukan kepuasan baik secara spiritual maupun materil (Setiadi, 2017). Hal ini, karena kebudayaan juga memberikan aturan bagi manusia (masyarakat).

Secara sosiologis, manusia sebagai makhluk sosial tentunya tidak akan pernah bisa hidup sendiri, dalam kehidupan sosialnya budaya hidup mempengaruhi cara manusia bersosialisasi. Artinya sebuah masyarakat baru bisa disebut sebuat masyakarat jika mempunyai kebudayaan dan pola hidup yang sama (Widiastuti, 2015) untuk mencapai keteraturan hidup bersama. Harapan ini didukung oleh kesadaran setiap individu untuk menyelaraskan setiap kepentingannya dengan kepentingan bersama (Suwarno, 2017).

Secara sederhana, Durkheim melihat individu dibentuk oleh masyarakat. Misalnya, pendapat masyarakat suku Dayak Ngaju ini sangat 'luar biasanya' mempengaruhi dan menentukan tindakan individu untuk mencapai suatu misi bersama, yaitu supaya memperoleh keselamatan dan ketenangan dalam hidupnya sebagai bentuk ketaatan dalam menjalani adat dan tradisi, baik dari orang yang memiliki pengetahuan ini maupun bagi orang yang memiliki firasat tersebut. Hal ini memang menunjukkan tentang suatu hubungan pedoman antar manusia atau kelompoknya.

\section{Kesimpulan}

Pelaksanaan tindakan manuhir ini menunjukkan tentang ketaatan orang suku Dayak Ngaju dalam adat dan tradisi, karena tindakan ini wajib dilakukan bagi orang yang memiliki firasat ini. Hal ini terkesan bahwa fakta tersebut begitu memaksa orang yang mempunyai firasat ini harus membuang firasat tersebut. Namun satu sisi apabila, mereka mendengarkan kata orang yang berpengetahuan juga sebagai bagian dari masyarakat kesukuan. Menurut tanggapan Dayak, manusia yang menaati seluruh hukum adat serta mematuhi Hukum Pali (tabu) dinamakan "manusia baik." 
Dari hal tersebut menunjukkan bahwa pendapat masyarakat suku Dayak ini sangat 'luar biasanya' mempengaruhi dan menentukan tindakan individu untuk mencapai suatu misi bersama, yaitu supaya memperoleh keselamatan dan ketenangan dalam hidupnya sebagai bentuk ketaatan dalam adat dan tradisi, baik dari orang yang memiliki pengetahuan ini maupun bagi orang yang memiliki firasat.

\section{Daftar Pustaka}

Ahmad, N. F. (2018). Fisiognomi Imam Syafii dalam Naskah Wirasat Sapii. Nusa: Jurnal Ilmu Bahasa Dan Sastra, 13(2), 301-315. https://doi.org/10.14710/nusa.13.2.301315

Akhlak, A., Arifin, M. B., \& Rijal, S. (2019). Pemali Dalam Masyarakat Etnik Banjar Di Kota Samarinda: Suatu Tinjauan Semiotika. Ilmu Budaya: Jurnal Bahasa, Sastra, Seni dan Budaya, 3(2), 121-130. https://doi.org/10.5281/ilmubudaya.v3i2. 1780

Alyana. (2019, Desember 16). Wawancara.

Bellah, R. N. (1991). Beyond Belief: Essays on Religion in a Post-Traditionalist World. University of California Press.

Dajak Booven. (2010). Manuhir (pengobatan alternatif dari Dayak Ngaju). Diambil 27 November 2019, dari http://dajakbooven.blogspot.com/2010/0 2/manuhir-pengobatan-alternatifdari.html

Darwis, R. (2017). Tradisi Ngaruwat Bumi Dalam Kehidupan Masyarakat (Studi Deskriptif Kampung Cihideung Girang Desa Sukakerti Kecamatan Cisalak Kabupaten Subang). Religious: Jurnal Studi AgamaAgama Dan Lintas Budaya, 2(1), 75-83. https://doi.org/10.15575/rjsalb.v2i1.2361

Dewi Sinta. (2018). Kajian Sosio-Teologis terhadap Pali Hari Selasa dalam Tradisi Masyarakat Suku Dayak Ngaju di Desa Batu Nyiwuh Kecamatan Tewah Kabupaten Gunung Mas. Palangka Raya: Sekolah Tinggi Agama Kristen Negeri Palangka Raya.

Doyle Paul Johnson. (1986). Sociological Theory: Classical Founders and Contemporary Perspectives/Doyle Paul Johnson. 1 ed. New York: Macmillan.

Eizabeth Nottingham. (1985). Religion and Society. Vol. 1. Underling: Doubleday.

Emile Durkheim. (2006). The Elementary Forms of the Religious Life. III. New York: Free Press.
Fridolin Ukur. (1971). Tantang Djawab Suku Dayak. Jakarta: Gunung Mulia.

Hans Scharer. (1963). Ngaju Religion the Conception of God among a South Borneo People. The Hague: Martinus Nijhoff.

Harpriyanti, H., \& Komalasari, I. (2018). Makna Dan Nilai Pendidikan Pamali dalam Masyarakat Banjar di Desa Barikin Kabupaten Hulu Sungai Tengah. STILISTIKA: Jurnal Bahasa, Sastra, Dan Pengajarannya, 3(2), 242-252. https://doi.org/10.33654/sti.v3i2.962

Heriansyah, M. (2017). Inventori Kepribadian Ideal Budaya Dayak Ngaju dalam Layanan Bimbingan dan Konseling. Jurnal Fokus Konseling, 3(2), 175-184184. https://doi.org/10.26638/jfk.318.2099

Muhammad, N. (2013). Memahami Konsep Sakral dan Profan dalam Agama-Agama. SUBSTANTIA: Jurnal Ilmu-Ilmu Ushuluddin, 15(2), 266-278. https://doi.org/10.22373/subtantia.v15i2. 4900

Nila Riwut. (2003). Maneser Panatau Tatu Hiang; Menyelami Kekayaan Leluhur (1 ed). Palangka Raya: Pusaka Lima.

Nurdiansah, N. (2017). Budaya Pamali Sebagai Landasan Pembelajaran Lingkungan Di Sekolah Dasar (Studi Kasus Pada Masyarakat Adat Kampung Naga Tasikmalaya). Pedagogi: Jurnal Penelitian Pendidikan, 4(1). Diambil dari https://journal.uniku.ac.id/index.php/ped agogi/article/view/1116

Pelu, I. E. A., \& Tarantang, J. (2018). Interkoneksi Nilai-Nilai Huma Betang Kalimantan Tengah dengan Pancasila. Jurnal Studi Agama dan Masyarakat, 14(2), 119-126. https://doi.org/10.23971/jsam.v14i2.928

Salim, M. (2016). Adat Sebagai Budaya Kearifan Lokal Untuk Memperkuat Eksistensi Adat Ke Depan. Al Daulah : Jurnal Hukum Pidana Dan Ketatanegaraan, 5(2), 244-255. https://doi.org/10.24252/ad.v5i2.4845

Sapulette, A. A. (2019). Interaksi Sosial Antarumat Beragama Di Desa Nania, Kota Ambon, Provinsi Maluku. DIALEKTIKA, 12(1), 1-10. https://doi.org/10.33477/dj.v12i1.786

Saripaini, S., \& Yusriadi, Y. (2016). Identitas Orang Bugis di Dabong, Kalimantan Barat. Khatulistiwa, 6(2). https://doi.org/10.24260/khatulistiwa.v6i 2.649 
Setiadi, E. M. (2017). Ilmu Sosial \& Budaya Dasar. Kencana.

Siti Zaenab. (2015). Metodologi Penelitian Pendidikan Kualitatif Prespektif Kekinian. Malang: Selaras.

Suwarno, S. (2017). Budaya Huma Betang Masyarakat Dayak Kalimantan Tengah Dalam Globalisasi: Telaah Konstruksi Sosial. Lingua : Jurnal Bahasa, Sastra, dan Pengajarannya, 14(1), 89-102. https://doi.org/10.30957/lingua.v14i1.23 7

Uniawati. (2014). Perahu dalam Pamali Orang Bajo: Tinjauan Semiotika Sosial Halliday. Jurnal Pendidikan dan Kebudayaan, 20(4), 568-578. https://doi.org/10.24832/jpnk.v20i4.166
Widiastuti, H. (2015). Pamali Dalam Kehidupan Masyarakat Kecamatan Cigugur Kabupaten Kuningan (Kajian Semiotik Dan Etnopedagogi). LOKABASA, 6(1). https://doi.org/10.17509/jlb.v6i1.3149

Yulianti, S. M. (2018). Konstruksi Sosial Dalam Praktik Pengobatan Oleh Dukun Dan Medis (Studi Di Kecamatan Lakudo Kabupaten Buton Tengah). Jurnal Neo Societal, 3(2). https://doi.org/10.33772/jns.v3i2.4024 